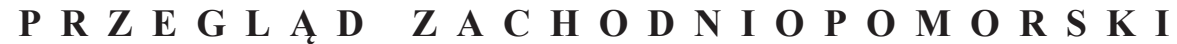 ROCZNIK XXXV (LXIV) ROK 2020 ZESZYT 1
}

\section{$\begin{array}{lllllllll}\mathbf{A} & \mathbf{R} & \mathbf{T} & \mathbf{Y} & \mathbf{K} & \mathbf{U} & \mathbf{L} & \mathbf{Y}\end{array}$}

\author{
SŁAWOMIR IWASIÓW \\ ORCID: 0000-0002-8555-8307 \\ Uniwersytet Szczeciński \\ e-mail: slawomir.iwasiow@usz.edu.pl
}

\section{SZCZECIŃSKI OŚRODEK TELEWIZYJNY W LATACH 60. XX WIEKU. EsTETYKA I POLITYKA}

Słowa kluczowe: media, telewizja, estetyka, polityka, Szczecin

Keywords: media, television, aesthetic, politics, Szczecin

W okresie od końca lat pięćdziesiątych do pierwszej połowy lat sześćdziesiątych polskie dziennikarstwo telewizyjne zaczęło zajmować miejsce równorzędne obok prasy i radia ${ }^{1}$. Telewizja zyskała uprawomocnienie w postaci ustawy o Komitecie do Spraw Radia i Telewizji z 1960 roku, która obowiązywała aż do lat dziewięćdziesiątych ${ }^{2}$. Jak duże było oddziaływanie tego medium? Według danych statycznych w roku 1960 zarejestrowano w Polsce 425919 abonentów telewizyjnych - ta liczba rosła w dużym tempie 3 .

${ }^{1}$ Pierwsze eksperymentalne prace nad uruchomieniem telewizji w Polsce rozpoczęto w roku 1935 w Państwowym Instytucie Telekomunikacyjnym w Warszawie, gdzie został utworzony właśnie w tym roku - Dział Telewizji. Jego szefem został Lesław Kędzierski (1911-1992) - wtedy inżynier, konstruktor, w późniejszych latach uznany naukowiec, profesor, teoretyk i praktyk techniki telewizyjnej (nazywany „ojcem polskiej telewizji”). Zob. Alina Karwowska-Lamparska, „Instytut Łączności kolebką polskiej telewizji”, Telekomunikacja i Techniki Informacyjne 3-4 (2009): 47-50.

2 Andrzej Matlak, „Nowa polska ustawa o radiofonii i telewizji”, „Zeszyty Prasoznawcze” 133 (1993), 1-2: 5.

${ }^{3}$ Są do dane Głównego Urzędu Statystycznego za rok 1960, obejmujące zarówno mieszkańców miast, jak i wsi. Należy dodać dla porównania, że w tym samym czasie abonentów radiowych 
W studiach TVP powstawały wtedy programy, które okazały się pierwowzorami dla materiałów emitowanych we współczesnych ramówkach. Były to: Dziennik Telewizyjny (1958), Pegaz (1959), Zrób to sam (1959), Jacek i Agatka (1962), Wielokropek (1963), 21 (1966) i wiele innych. Wszystkie nadawano oczywiście w ramach „Jedynki” - „Dwójka” została uruchomiona dopiero w październiku 1970 roku.

Na przełomie dekad powołano do życia lokalne redakcje telewizyjne, również w Szczecinie ${ }^{4}$. W tym okresie przewodnią rolę wśród szczecińskich mediów odgrywała prasa - choć i na tym polu aktywności dziennikarskiej wciąż trudno było mówić o stabilnej sytuacji (nie funkcjonowało na przykład zbyt wiele pism kulturalnych czy specjalistycznych). Dużą rolę w przeorganizowaniu lokalnej sieci mediów, a więc także dziennikarstwa telewizyjnego, odegrały wydarzenia roku 1956, które zapewniły lokalnym dziennikarzom chwilową swobodę 5 . Od tego momentu można mówić o nowym okresie w powojennej historii polskich mediów - także na Pomorzu Zachodnim, pod wieloma względami regionie specyficznym ${ }^{6}$.

„Telewizja szczecińska” - to znaczy jaka? Taka, która była związana z miastem, wpływała na społeczność lokalną, omawiała i organizowała kulturę w regionie. Jej genezy należy szukać w momencie, gdy na dobre zaczęła kształtować się polska tożsamość przejętego w 1945 roku Stettina. Z politycznego punktu widzenia był to okres naznaczony wieloma wydarzeniami, ideami, mitami. Szczecin dwóch pierwszych powojennych dekad powinien być zatem dzisiaj kojarzony między innymi z takimi kategoriami, jak: bliskość granicy na Odrze i Nysie, przymusowe migracje, mity o morskości i portowym charakterze miasta, specyficzna struktura społeczna, a przede wszystkim mikrokultura marynarska.

było w Polsce ponad 5 milionów. Zob. Główny Urząd Statystyczny, Bank Danych Polska, dostęp 5.04.2019, https://bdp.stat.gov.pl/.

4 Zbigniew Puchalski, „Telewizja”, w: Encyklopedia Szczecina. Tom II. P-Ż, red. Tadeusz Białecki (Szczecin: Uniwersytet Szczeciński, 2000), 518.

5 Tadeusz Białecki, Prasa Pomorza Szczecińskiego w latach 1945-1975 (Szczecin: Wydawnictwo Naukowe Wyższej Szkoły Pedagogicznej w Szczecinie, 1978), 3-27. Por. Robert Jurszo, IPN: Październikowa odwilż dała prasie na krótko większą swobodę, dostęp 4.2019, https:// dzieje.pl/aktualnosci/ipn-pazdziernikowa-odwilz-dala-prasie-na-krotko-wieksza-swobode.

6 Nie ma zbyt wielu opracowań medioznawczych dotyczących powojennych mediów na Pomorzu Zachodnim - w pewnym sensie największą pracę w tym zakresie wykonali związani $\mathrm{z}$ regionem historycy, cytowani również w niniejszym artykule. Natomiast istnieją opracowania na temat współczesnych mediów szczecińskich (w tym telewizji). Zob. Jan Kania, Robert Cieślak, red., Media lokalne w Szczecinie (Szczecin: Wydawnictwo Naukowe Uniwersytetu Szczecińskiego, 2011). 
Nie bez znaczenia były oczywiście także społeczne zrywy - przede wszystkim wieńczące dekadę strajki w grudniu 1970 roku? .

„Szczecińska”, w odniesieniu do telewizji, oznacza zatem także lokalność, tworzenie kultury miejsca, nadawanie mu określonego wizerunku. Można by jednakowoż toczyć spór, czy w ogóle istnieje coś takiego jak „kultura szczecińska”. Z podobnym problemem - dotyczącym pojęcia „kultura zachodniopomorska" - zmagał się między innymi Erazm Kuźma, gdy pisał historię literatury na Pomorzu Zachodnim ${ }^{8}$. Zostawiając te rozważania na dalszym planie, można przyjąć, że specyfika Szczecina i jego kultury przeniknęła również do sztuki uprawiania dziennikarstwa telewizyjnego, a telewizja - zmieniła oblicze kultury miasta.

Z takiego punktu widzenia „lokalność” mediów (prasy, radia i telewizji) oznacza ich jedyny w swoim rodzaju charakter - zarówno terytorialny, jak i społeczny. „Pierwszy dotyczy ograniczonego w przestrzeni obszaru, drugi natomiast podstawowych relacji społecznych" - pisał Jan Kania, definiując media lokalne9. Czy w takim razie, pod względem rodzajowym czy gatunkowym, te media różniły się od ogólnopolskich? Raczej nie - jeżeli coś je rzeczywiście wyodrębniało, była to specyficzna tematyka związana ze sprawami regionu (osobami, miejscami, wydarzeniami itd.). Twórcą szczecińskiej TV był inż. Jerzy Fedorowski, szef Doświadczalnego Ośrodka Telewizyjnego (DOT) jeszcze w okresie 1955-1960. Potem rolę redaktora programowego przejął Marian Syganiec, który pełnił tę funkcję w latach 1961-1964. Kolejno w latach sześćdziesiątych telewizją kierowali: Tadeusz Kurek (1963-1965), Stanisław Borowiecki (1965-1968) i Ryszard Liskowacki (1969-1971) ${ }^{10}$.

Mimo że początki szczecińskiej telewizji sięgają 1955 roku, od kiedy funkcjonowała pod szyldem DOT-u, lokalny program zainaugurowano 27 kwietnia 1960 roku - w dzień po piętnastej rocznicy zajęcia miasta przez Armię Czerwoną. Tego rodzaju „zbiegów okoliczności” w historii mediów na Pomorzu Zachodnim znajdziemy więcej, ale szczeciński przypadek jest szczególny, ponieważ to

\footnotetext{
${ }^{7}$ Michał Paziewski, Grudzień 1970 w Szczecinie (Szczecin: IPN, 2013).

${ }^{8}$ Erazm Kuźma, „O literaturze na Pomorzu”, w: Literatura na Pomorzu Zachodnim do końca XX wieku. Przewodnik encyklopedyczny, red. Erazm Kuźma, Inga Iwasiów (Szczecin: KurierPress, 2003), 14-15.

9 Jan Kania, „Podstawy metodologiczne wyodrębnienia mediów lokalnych”, Edukacja Humanistyczna 22 (2010), 1: 11.

${ }^{10}$ Puchalski, „Telewizja”, 518.
} 
właśnie w Szczecinie, w okresie powojennym, splatały się ze sobą wątki estetyczne i polityczne - wystarczy przypomnieć pierwszy numer „Kuriera Szczecińskiego" z 7-8 października 1945 roku, relacjonujący przejmowanie administracji z rąk Niemców. To znany fakt: rzeczownik „Niemcy” pisano w polskiej prasie małą literą. Media pełniły wtedy zdecydowanie propagandową, perswazyjną funkcję - miały dobitnie przekazywać określone treści.

Telewizja również nie uniknęła wpływów polityki, co nie znaczy, że jej estetyka była wyłącznie podporządkowana ideologii. Chciałbym podkreślić - w tym wypadku jak sądzę kluczowe - znaczenie terminu „estetyka” w odniesieniu do historii telewizji czy też w ogóle historii mediów masowych w XX i XXI wieku. Przy czym estetykę i politykę, a także ich związki, rozumiem tak, jak przedstawił do Jacques Rancière w eseju Dzielenie postrzegalnego. Estetyka i polityka (oryg. wyd. 2000). Według francuskiego filozofa sztuka zawsze oddziałuje na politykę, a polityka - na estetykę/sztukę (mimo że są kategoriami wyraźnie odrębnymi!) ${ }^{11}$. Tę zależność oddaje Rancièrowski termin „dzielenie postrzegalnego”, oznaczający społeczną partycypację $\mathrm{w}$ tworzeniu różnych porządków: $\mathrm{w}$ tym przede wszystkim politycznego i estetycznego, ale także wielu innych: naukowego, edukacyjnego, związanego z pracą, czasem wolnym, rozrywką etc. W nie mniejszym stopniu „dzielenie postrzegalnego” dotyczy mediów - również telewizji w wymiarze lokalnym.

Jak twierdzi Martin Shuster, autor książki New Television. The Aesthetics and Politics of a Genre, nie sposób oddzielić genezy i rozwoju telewizji od wartości estetycznych, związanych z innymi dziedzinami sztuki, takimi jak: fotografia, film, a nawet literatura ${ }^{12}$. Zatem analizując historię telewizji regionalnej, w tym wypadku ośrodka szczecińskiego, nie można pominąć jej wymiaru estetycznego (czyli sposobu prezentowania określonych treści poprzez bardzo konkretne użycia słowa, obrazu i dźwięku, o czym piszę szerzej w niżej analizowanych przykładach), a także związków estetyki z właściwą dla okresu lat sześćdziesiątych orientacją polityczną. Patryk Pleskot, zbierając informacje prasowe na temat wpływu telewizji na życie Polaków w tym czasie, posłużył się określeniem „mała stabilizacja chaosu” - jak sądzę dobrze oddaje ono stan ówczesnego dziennikarstwa telewizyjnego, w jakimś stopniu rozdartego pomiędzy technicznym

\footnotetext{
11 Jacques Rancière, Dzielenie postrzegalnego. Estetyka i polityka, tłum. Maciej Kropiwnicki i Jan Sowa, wstęp Magda Pustoła (Kraków: Koroporacja Ha!art, 2007).

12 Martin Shuster, New Television. The Aesthetics and Politics of a Genre (Chicago: University of Chicago Press, 2017), 3.
} 
i estetycznym nowatorstwem, artystycznymi aspiracjami zespołów redakcyjnych a politycznymi naciskami ze strony PZPR- ${ }^{13}$. Estetyka i polityka - te dwa „pola” trudno zatem w perspektywie rozważań na temat pionierskich lat szczecińskiego dziennikarstwa telewizyjnego, w perspektywie filozofii Rancièrowskiej, postrzegać rozdzielnie.

Pierwsze kroki lokalnych dziennikarzy telewizyjnych opisał między innymi Andrzej E. Androchowicz (1932-2006), reporter, autor filmów dokumentalnych, jeden z prekursorów szczecińskiej telewizji.

Androchowicz wspominał o dwu istotnych faktach: po pierwsze - telewizja w Szczecinie (i nie tylko tu) narodziła się w środowisku radiowców, co pozostaje nie bez znaczenia dla jej technologicznych uwarunkowań oraz estetyki, przede wszystkim w pierwszych latach działalności ${ }^{14}$, a po drugie - pomysł został podpatrzony w Poznaniu, co należy dołączyć do listy „długów”, jakie Pomorze Zachodnie zaciągnęło w Wielkopolsce (jednym z nich jest ,importowanie” Piotra Zaremby, pierwszego prezydenta Szczecina) ${ }^{15}$. „Ponieważ w latach 1960-65 Szczecin nie miał połączenia zwrotnego z Warszawą, żeby cokolwiek nadać w programie ogólnopolskim (program był emitowany na żywo) - należało jechać do ośrodka, który miał takie możliwości. Najczęściej, bo najbliżej, jeździliśmy do Poznania" - wspominał Androchowicz ${ }^{16}$. Warto dodać, że to właśnie ze stolicy Wielkopolski nadawany był, co wydaje się nieco paradoksalne, program, z którym być może najbardziej szczecińska telewizja była kojarzona w skali kraju w tamtym okresie, czyli $Z$ bocianiego gniazda ${ }^{17}$. I na tym, między innymi, polega główna różnica estetyki szczecińskiej wobec estetyki ogólnopolskiej - w szczecińskim ośrodku to właśnie tematyka morska przez wiele lat wpływała na styl uprawiania dziennikarstwa telewizyjnego.

13 Patryk Pleskot, „Telewizja w życiu Polaków lat sześćdziesiątych”, Dzieje Najnowsze 34 (2002), 4: 15.

${ }^{14}$ Pierwsze próby telewizyjne w Polsce datuje się na 1938 rok, kiedy nadawano sygnał z gmachu Prudentialu w Warszawie - owe eksperymenty zostały przerwane działaniami wojennymi. Powrócono do nadawania sygnału telewizyjnego na początku lat pięćdziesiątych. W 1957 roku w Polsce zarejestrowano 21 tysięcy odbiorników telewizyjnych. W 1969 roku powstało Centrum Radiowo-Telewizyjne w Warszawie przy ul. Woronicza. Zob. Tomasz Goban-Klas, Cywilizacja medialna. Geneza, ewolucja, eksplozja (Warszawa: WSiP, 2005), 93-95.

15 Andrzej Androchowicz, „Zabawa w telewizję”, w: Stowem i piórem. 50 lat dziennikarstwa na Pomorzu Zachodnim, red. Tadeusz Białecki (Szczecin: SDRP, 1996), 117.

16 Tamże.

17 Tamże. 
To za sprawą materiałów filmowych Androchowicza - wchodzącego w skład nielicznej wtedy ekipy reporterów, realizatorów i prezenterów - w latach sześćdziesiątych Szczecin zaczął być miejscem charakterystycznym; miasto było rozpoznawalne dzięki przemysłowi stoczniowemu, rejsom do Szwecji czy Filipinkom, pierwszemu polskiemu girlsbandowi (ich ,teledyski” nierzadko miały w tle morskie fale). Sam Androchowicz od początku zajmował się tematyką morską, nakręcił między innymi film dokumentalny Kapitan kapitanów (1968), przedstawiający sylwetkę Konstantego „Macaja” Maciejewicza. W kolejnych dekadach reporter pokazywał miasto wielokrotnie, choćby w filmach Pierwsza szczecińska (1971), Szczecin - pierwsze dni (1974) czy Polska nad Battykiem (1986).

Krótko rzecz ujmując: telewizja powstała w czasach, kiedy zaczął tworzyć się określony wizerunek Szczecina. Jej estetyka od początku była, by tak rzec, ideologiczna, retoryczna, perswazyjna. Co wtedy nadawano ze szczecińskiego studia?

Program publicystyczny nosił tytuł Gość kamer, ponadto na antenie mówiono o sprawach społecznych, gospodarce, sporcie. Wyróżniały się audycje: Gimnastyka dla Pań, jak również Kramik z Muzami o tematyce kulturalnej. Ze względów technicznych reporterski Telenotatnik realizowano ze studia zaaranżowanego w kinie. Był także poradnik dla widzów, w którym pokazywano, jak obsługiwać telewizor - Skrzynka techniczna. Najbardziej lokalny wymiar miał wspomniany powyżej cykl $Z$ bocianiego gniazda. Dzieci oglądały jedną z pierwszych polskich „dobranocek” - Wicka Marynarzyka i wujka Mariana. Zapowiedzi programów czytały spikerki wywodzące się ze środowiska teatralnego, aktorskiego. Mniej więcej taką ramówką telewidzowie szczecińscy musieli się zadowolić przez kilka lat, ponieważ program ogólnopolski był dostępny dopiero od 13 lutego 1965 roku, kiedy wybudowano nadajnik w Kołowie ${ }^{18}$. Jak te programy mogły wpływać na lokalną społeczność?

W tamtym okresie telewizja zmieniła „układ sił” nie tylko w mieście, ale także w prywatnych domach. Sam telewizor przeorganizował - właśnie w estetycznym i równocześnie politycznym sensie - przestrzeń mieszkań meblowanych

18 Wtedy także szczecińska telewizja lokalna zaczęła wnosić swój wkład do programu ogólnopolskiego. W roku 1965 powstało nowe studio w Szczecinie i po raz pierwszy na antenę ogólnopolską nadano z niego w czerwcu tego właśnie roku felieton filmowy pod tytułem Granica. Zob. 55 lat Telewizji Szczecin - historia telewizji z 55-letnim doświadczeniem, dostęp 5.04.2019, szczecin.tvp.pl. 
w duchu ,polskiego designu” lat sześćdziesiątych ${ }^{19}$. John Urry tak opisał dominację telewizora:

W salonie odbiornik telewizyjny skupia na sobie spojrzenia wszystkich, którzy tam wchodzą, niezależnie od tego, czy jest włączony, czy nie. Zwykle reszta umeblowania zwrócona jest w stronę telewizora, czekając, aż ten ożyje. To centrum pokoju. Odbiornik telewizyjny i reszta mebli konstytuują się nawzajem. Dopiero wspólnie tworzą właściwe miejsce, dające przebywającym w nim ludziom poczucie zadomowienia dzięki zapośredniczanej przez telewizję wymianie kulturowej z odległym światem ${ }^{20}$.

Z tego też powodu telewizja idealnie wpisała się w socjalistyczny projekt budowania ,naszej małej stabilizacji”, a w domach pojawiały się odbiorniki - Koral, Lazuryt czy Topaz, produkowane przez Warszawskie Zakłady Telewizyjne. Telewizja dokonała zatem przeobrażenia kulturowego, a telewizor - jako przedmiot - zaczął skupiać ludzi wokół siebie niczym w dawnych czasach płomień domowego ogniska. „Telewizja podbiła ziemię i jej mieszkańców” - konstatował Zygmunt Bauman ${ }^{21}$. Dodajmy, że na ,pionierskim” terytorium Pomorza Zachodniego telewizja odgrywała jeszcze jedną rolę - scalała, dzięki swojej estetyczno-ideowej ofercie programowej, wciąż jeszcze na początku lat sześćdziesiątych niespójną tkankę społeczną. To znany fakt: wtedy wciąż jeszcze część mieszkańców obawiała się powrotu Niemców.

Ten sposób estetyczno-politycznego myślenia - a przede wszystkim postrzegania siły i roli telewizji - zaczyna się właśnie u progu siódmej dekady XX wieku. Jak zauważył Pierre Bourdieu: „Najważniejszym zjawiskiem, trudnym do przewidzenia, było nadzwyczajne rozszerzenie wpływu telewizji na całość produkcji kulturowej, w tym produkcji naukowej i artystycznej"’22. Te słowa francuski socjolog wypowiedział w telewizji, wygłaszając wykłady na temat tego medium w połowie lat dziewięćdziesiątych. To być może truizm, ale telewizja w krótkim czasie zmieniła świat. Czy pod jej wpływem odmieniał się także Szczecin?

19 Pleskot, „Telewizja w życiu Polaków”, 115-116.

${ }^{20}$ John Urry, Socjologia mobilności, tłum. Janusz Stawiński (Warszawa: PWN, 2009), 99.

${ }^{21}$ Zygmunt Bauman, Społeczeństwo w stanie oblężenia, tłum. Janusz Margański (Warszawa: Sic!, 2006), 184.

22 Pierre Bourdieu, O telewizji. Panowanie dziennikarstwa, red. naukowa i przedmowa Małgorzata Jacyno, tłum. Karolina Sztandar-Karolewska, Anna Ziółkowska (Warszawa: Wydawnictwo Naukowe PWN, 2009), 65-66. 
Słowa ze wspomnienia Andrzeja E. Androchowicza mogą dowodzić retoryczności tak postawionego pytania - dziennikarze telewizyjni wpłynęli na postrzeganie Szczecina, choć przecież sami zmieniali się razem z miastem, odnajdywali dla siebie nowe role. Androchowicz miał wykształcenie ekonomiczne, od połowy lat pięćdziesiątych pracował jako dziennikarz prasowy, między innymi w „Głosie Szczecińskim”. Marian Syganiec (1925-1967) był radiowcem i współtwórcą Doświadczalnego Ośrodka Telewizyjnego. Podobnie Władysław Daniszewski (1929-2007), jeden z założycieli szczecińskiej telewizji, wywodzący się ze środowiska radiowego. Wspomniany pierwszy program wieczorny dla dzieci pod tytułem Wicek Marynarzyk $i$ wujek Marian tworzyli Syganiec oraz Juliusz Kornacki (ur. 1930) i Dagny Koczorowska (ur. 1930) - małżeństwo aktorów związanych z Teatrem Lalek „Pleciuga”. Malwina Nowak (1933-2015) także była aktorką „Pleciugi” - w 1960 roku została pierwszą spikerką szczecińskiej TV²3.

To tylko niektóre postaci z życiorysami wpisanymi w historię szczecińskiego ośrodka telewizyjnego - miały one, w różny sposób, wpływ na jej kształt i styl emitowanych programów. Faktem jest jednak, że telewizję stworzyli dziennikarze prasowi, radiowcy, aktorzy, także pisarze - i tak jak całkiem słusznie twierdzi się współcześnie, że telewizję światową ukształtowała dekada lat pięćdziesiątych i dziennikarstwo „newsowe" 24 , tak w Polsce telewizje regionalne i zespoły je tworzące w latach sześćdziesiątych przetarły szlaki dla swoich następców ${ }^{25}$. Być może w tym aspekcie trzeba by także, na podstawie szerszych badań, szukać oryginalności telewizji szczecińskiej. W czym mogła się ona przejawiać?

O ramówce i zespole wspomniałem powyżej - a jakich wrażeń estetycznych dostarczały szczecińskie programy? Na czym polegała ich oryginalność? Pierwsze skojarzenie audiowizualne to ,ident” przedstawiający widok na port - obraz ten przez długie lata towarzyszył programom nadawanym ze szczecińskiego ośrodka telewizyjnego. Plansza wyglądała tak: na spokojne fale Odry pada ostre

\footnotetext{
23 Androchowicz, „Zabawa w telewizję”, 114.

${ }^{24}$ Sig Mickelson, The Decade that Shaped Television News. CBS in the 1950s (Westport: Praeger Publishers, 1998).

25 Związki lokalności i komunikowania społecznego wykazywali współcześni badacze mediów, między innymi Stanisław Michalczyk, który stwierdził, że: „Ludzie poinformowani, mający świadomość sensu oraz możliwości działania zarówno zbiorowego, jak i indywidualnego, w celu zaspokojenia swych potrzeb jednostkowych, zbiorowych czy społecznych stają się bardziej zaangażowani i sprawni zarówno w wymiarze indywidualnym, jak i społecznym. Miejsce, w którym ludzie tak mogą żyć, staje się im jeszcze bliższe, niżby to wynikało tylko z samego urodzenia się tam lub zamieszkania”. Stanisław Michalczyk, Media lokalne w systemie komunikowania (Katowice: Wydawnictwo Uniwersytetu Śląskiego, 2000), 30.
} 
światło słoneczne. Właściwie to rzeka jest na pierwszym planie zdjęcia, jej nurt przecina jedynie niewielka łódź motorowa. W dolnym prawym rogu kadru cumuje statek, dziobem zwrócony do widza, nieco samotny w obliczu dość dużego rozlewiska i sięgającej aż po horyzont linii nabrzeża. W dalszym planie, u góry kadru - Elewator Ewa, widoczny od strony krótszego boku, mniejszy jakby niż w rzeczywistości. W tle majaczą spokojne żurawie dźwigów i miniaturowe w tej perspektywie okręty. Na wszystko oko aparatu patrzy z góry $-\mathrm{z}$ „bocianiego gniazda". Z oddali słychać dźwięk okrętowej syreny.

Refleksja może być taka: port wydaje się opustoszały, zaspany, nieruchliwy. I oczywiście jest czarno-biały, jak cała ówczesna telewizja. Czy tak wygląda nadmorskie miasto - centrum handlu, przemysłu, turystyki?

To interesujące zestawienie obrazu i dźwięku, ponieważ przeziera z tej planszy pewna umowność, sztuczność, ale i artystyczność, malarskość telewizyjnego przekazu - to przecież nieruchomy obraz. Zdjęcie wykonane przez Witolda Chromińskiego (1913-1977) sugerowało widzom, czego powinni byli się spodziewać, jakiej zawartości programowej mogli oczekiwać. Dźwięk syreny podkreślał „morskość" przekazu, jakby nie wystarczał ten spokojny portowy krajobraz.

Swoista pocztówkowość planszy niekoniecznie musiała iść w parze z tym, co rzeczywiście działo się w mieście - port w tamtym okresie funkcjonował raczej dynamicznie ${ }^{26}$. Obraz zapowiadał jednakowoż tematykę podejmowaną przez dziennikarzy i reporterów w początkowych latach działalności telewizji szczecińskiej. Lokalność/regionalność, morska atmosfera, portowe tradycje i ewoluujący przemysł oraz kultura nierzadko popularna (w wykonaniu wspomnianych Filipinek) - to cechy charakterystyczne nadawanych programów, a przy tym najważniejsze, podkreślane po wojnie, kierunki rozwoju Szczecina. To także trzeba użyć tego określenia - mity o mieście, które z powodzeniem, w pewnych zmieniających się okolicznościach, przetrwały do czasów współczesnych. Szczecin to miasto: „morskie”, „rzeczne”, „portowe”, „przemysłowe”, „,nowoczesne” „kulturalne”, „otwarte”, „zielone”, to wreszcie (dzisiaj) - „pływający ogród”. Niektóre z tych określeń są zapewne prawdziwe, inne - działały przez dekady jak syrena z planszy szczecińskiej telewizji, wywołując określone skojarzenia.

${ }^{26}$ Szczeciński port z reguły pokazywano jako miejsce ruchliwe. Warto porównać to zdjęcie firmujące szczecińską TV z pocztówkowymi obrazami, które omawia Roman Czejarek w jednej ze swoich książek, na przykład w albumie Kolorowy Szczecin na starych pocztówkach. Port, nabrzeża i okolice Odry były przedstawiane jako miejsca zaludnione, z dużą liczbą okrętów i łodzi. Zob. Roman Czejarek, Kolorowy Szczecin na starych pocztówkach (Łódź-Szczecin: Księży Młyn Dom Wydawniczy, 2013). 
Można by się zastanowić wszak, w jaki sposób ten statek, to nabrzeże z elewatorem, ten dźwięk, reprezentowały miasto i jego charakter? Czy może było tak, że plansza niczego nie odzwierciedlała, a była jedynie wyrazem przekonań, idei czy światopoglądów osób, które były odpowiedzialne za identyfikację graficzną? To był przecież jeden z planów zgodnych z socjalistyczną polityką państwa - stworzyć na Ziemiach Zachodnich silny ośrodek portowy. Czy można było wybrać wtedy inny fragment miasta i czy dzisiaj kojarzylibyśmy Szczecin inaczej, z odmienną estetyką?

Plansza z Odrą, okrętem i Elewatorem Ewa jest częścią szczecińskiej, mitologizowanej w okresie PRL-u morskości. Przetrwała ona - i plansza, i morskość - do lat dziewięćdziesiątych, wyświetlana na ekranach telewizorów właściwie w niezmienionej postaci. Jej estetyka stanowi o wizerunku miasta - fale, okręty, port, wszystko to składa się na spójną estetycznie całość. Otwiera się w tym miejscu kolejny problem do rozważenia: to, co dzisiaj przyjmujemy jako charakterystyczne dla Szczecina (lub jakiegokolwiek innego regionu w Polsce) w tamtym okresie było „sterowane” centralnie i zasilane przez idee polityczne. Czy wszystkie audycje telewizyjne takie były?

Wspomniałem, że pierwszym programem dla dzieci był Wicek Marynarzyk $i$ wujek Marian - można rzec, iż „klasyczna” dobranocka nadawana w telewizji szczecińskiej od lipca 1960 roku ze studia DOT-u przy ul. Tkackiej. Twórcą dobranocki był Marian Syganiec (grał też wujka Mariana), teksty pisała Irena Łuczak, a postać Wicka odgrywali aktorzy z Teatru Lalek „Pleciuga” (Juliusz Kornacki i Dagny Koczorowska). Przygody piegowatego marynarzyka oglądały tylko dzieci ze Szczecina i najbliższych okolic - to był jeden z kilku specyficznych programów lokalnej telewizji. Dobranocka to przykład powiązania dwu sfer, o których mowa w niniejszym artykule - estetyczność audycji jest bezdyskusyjna (był to po prostu kukiełkowy minispektakl), natomiast łączy się ona z wyraźną tematyką, w tym wypadku marynistyczną, lokalną, na swój sposób utrwalającą obraz morskiego Szczecina.

Idąc nieco innym tropem, należy zauważyć, iż nie brakowało w latach sześćdziesiątych filmów opowiadających o codzienności mieszkańców miasta, robotników, dokerów, marynarzy, urzędników. Ciekawe, że sporo spośród nich powstało za sprawą filmowców z innych ośrodków, między innymi z Warszawy czy z Łodzi. Jednym z nich jest dokument Szczecin - Port (1964) autorstwa Marii Tymowskiej (scenariusz) i Radosława Sobeckiego (realizacja), którzy 
w 1965 roku otrzymali za niego „Srebrną Fregatę” na II Ogólnopolskim Przeglądzie Krótkometrażowych Filmów Morskich w Świnoujściu.

Również z łódzkim środowiskiem dokumentalistów był związany Wiesław Drymer (1928-2007), który sportretował miasto w filmie zatytułowanym W Szczecinie (1965). Dokument wyraźnie podkreśla morski, portowy charakter miasta, autorzy posiłkują się przy tym mitem o słowiańskości miasta. „Szczecin - tu, u podnóża piastowskiego zamku, pod osłoną baszt i murów miejskich, znajdowały niegdyś schronienie kupieckie i rybackie. Dzisiejszy olbrzymi port szczeciński rozłożył się między dwiema głównymi odnogami Odry: Odrą Zachodnią i Regalicą" - mówi lektor. Styl tego filmu podkreśla odzywająca się co jakiś czas okrętowa syrena.

Warto jeszcze przypomnieć dokumentalny materiał przygotowany przez Stanisława Manturzewskiego (scenariusz) i Jerzego Kadena (komentarz i realizacja) pod tytułem Dwie kroniki Szczecina (1965). Film przedstawia powojenne dwudziestolecie, od momentu przejęcia miasta przez władze polskie, do połowy lat sześćdziesiątych. Przeplatają się w nim zdjęcia z tych pierwszych lat panorama zrujnowanego portu, pracujący mieszkańcy, ,pionierzy” rozładowujący pociągi - z obrazami późniejszymi, ukazującymi Szczecin jako aktywnie rozwijający się ośrodek przemysłu portowego, ale też miejsce, któremu nieobce są kultura i nauka. Symptomatyczny jest fragment, w którym mężczyzna, stojąc na drabinie, przy pomocy młotka zbija ze ściany budynku litery niemieckiego napisu, być może nazwy sklepu. „Zaczyna się odbudowa portu i miasta” - mówi lektor. To dobry przykład retoryki filmowej owych czasów, pełnej paradoksów szczecinianie wspólnie odbudowywali miasto, ale poprzez skuwanie, usuwanie, zdrapywanie dokładnie wyselekcjonowanych śladów przeszłości.

Pytanie jednak: na ile te obrazy - przede wszystkim filmy i ich bardzo konkretne tematy - faktycznie oddziaływały na świadomość Polaków (w tym również mieszkańców Szczecina i okolic)? Dużej wiedzy na ten temat dostarcza statystyka - wiadomo dzisiaj, że w ciągu dekady lat sześćdziesiątych liczba zarejestrowanych abonentów telewizji wzrosła dziesięciokrotnie. Jeśli w 1960 roku zarejestrowanych odbiorców sygnału telewizyjnego było nieco ponad 400 tysięcy, to w roku 1970 były to już ponad 4 miliony ${ }^{27}$.

Przy czym, jak wskazuje cytowany wcześniej Patryk Pleskot, liczba abonentów nie stanowiła miarodajnego odzwierciedlenia dla faktycznej liczby

${ }^{27}$ Te dane liczbowe przedstawiają obraz w skali kraju - dla miast i wsi łącznie. Zob. Główny Urząd Statystyczny, Bank Danych Polska, dostęp 5.04.2019, https://bdp.stat.gov.pl. 
telewidzów w Polsce - na przestrzeni lat sześćdziesiątych mogło być ich nawet pięć razy więcej ${ }^{28}$. Poza tym obserwowano, by tak rzec, duże oczekiwania społeczne wobec stosunkowo nowej technologii - przynosiła ona zyski, była nawet powodem do dumy, ale też stwarzała napięcia między popytem a podażą. Telewizorów produkowano za mało, nie były one najlepszej jakości, szybko się psuły. „Rynek usług radiowo-telewizyjnych był tak daleko w tyle za zapotrzebowaniem społeczeństwa, że stał się przedmiotem nieustannej krytyki i źródłem irytacji przez cały okres lat 60 "'29.

Jak zatem telewizja ukształtowała polskie społeczeństwo w latach sześćdziesiątych? „Najsilniej zaznaczyła się chyba w dziedzinie rozrywki i czasu wolnego, który pod jej wpływem uległ reorganizacji. Dla wielu mały ekran stał się zastępstwem albo substytutem kina, teatru, radia bądź spaceru; program dnia zaczęto układać podług programu TV" ${ }^{30}$.

Podobne wnioski można wysnuć z perspektywy telewizji lokalnej. Z jednej strony to, co oglądano w latach sześćdziesiątych na ekranach telewizorów niejednokrotnie odzwierciedlało codzienność Szczecina, a z drugiej strony właśnie telewizja - jako nowoczesne medium i technologiczna zdobycz lat sześćdziesiątych - zaczęła konstruować rzeczywistość. „Konstruowanie” nie znaczy bynajmniej, że tworzono jakiś nieprawdziwy, zafałszowany obraz miasta i jego mieszkańców. Jak twierdzi Anthony Giddens:

W sumie w warunkach nowoczesności środki przekazu nie tyle odzwierciedlają rzeczywiste zdarzenia, ile częściowo je tworzą. Ale wcale stąd nie wynika - i nie należy wyciągać takiego wniosku - że media utworzyły autonomiczny obszar „hiperrzeczywistości”, zbudowany wyłącznie ze znaku i obrazu ${ }^{31}$.

Konstruowanie to oczywiście także ideologizowanie, perswazyjność, „nadinterpretowanie" - i w tym sensie również można rozpatrywać estetykę obrazów telewizyjnych z lat sześćdziesiątych.

28 Pleskot, „Telewizja w życiu Polaków”, 119.

29 Tamże, s. 121.

30 Tamże, s. 135.

31 A. Giddens, Nowoczesność i tożsamość. , Ja” i spoleczeństwo w epoce późnej nowoczesności, tłum. Alina Szulżycka (Warszawa: Wydawnictwo Naukowe PWN, 2010), 45. Warto dodać dla porządku, że tym twierdzeniem brytyjski socjolog dyskutuje z „teorią symulakrów” Jeana Baudrillarda. Zob. Jean Baudrillard, Symulakry i symulacja, tłum. Sławomir Królak (Warszawa: Sic!, 2005). 
Szczecin z tamtych obrazów jawi się jako przestrzeń, mimo wszystko, nowoczesna, zarządzana w sposób postępowy, dająca obywatelom mieszkanie, pracę i rozrywkę. Ten przekaz umacniała nie tylko telewizja, wypływał on także z innych mediów - radia i prasy. Nie ma na to tutaj miejsca, ale warto byłoby porównać je ze sobą, zestawiając z nie mniej sugestywnymi literackimi reprezentacjami miasta - choćby z powieściami Ryszarda Liskowackiego, na przykład Końcem próby (1962) czy Dniem siódmym i znowu pierwszym (1963), które ukazywały Szczecin jako miasto „trudne”, ale dające nadzieję na przyszłość. Zadanie dziennikarzy, a szczególnie reporterów telewizyjnych, nie polegało bowiem tylko na odtwarzaniu wydarzeń, przekazywaniu faktów czy ich komentowaniu, ale także stanowiło rodzaj twórczości estetycznej, ,,artystycznej”, w takim znaczeniu, w jakim film może być nie tylko przedstawieniem świata, ale i jego przetworzeniem, nie tylko prawdą, ale przede wszystkim fikcją, równocześnie relacją oraz (nad)interpretacją. W latach sześćdziesiątych działały mechanizmy cenzury, przekazy medialne były sterowane centralnie, pojęcia ze słownika terminów dziennikarskich - jak „wolność słowa”, „,rzetelność” czy „fakty” - miały mimo wszystko odmienne niż dzisiaj znaczenie. Dlatego między innymi telewizyjne obrazy Szczecina z tamtego okresu są zmitologizowane, zideologizowane, perswazyjne. Co nie znaczy, że tylko tak należy je postrzegać - przede wszystkim mając na uwadze całe spektrum związków estetyki i polityki na gruncie społecznym.

\section{Bibliografia}

55 lat Telewizji Szczecin - historia telewizji z 55-letnim doświadczeniem. Dostęp 5.04.2019. Szczecin.tvp.pl.

Androchowicz, Andrzej. „Zabawa w telewizję". W: Stowem i piórem. 50 lat dziennikarstwa na Pomorzu Zachodnim, red. Tadeusz Białecki, 113-119. Szczecin: SDRP, 1996.

Baudrillard, Jean. Symulakry i symulacja. Tłum. Sławomir Królak. Warszawa: Sic!, 2005.

Bauman, Zygmunt. Spoleczeństwo w stanie oblężenia. Tłum. Janusz Margański. Warszawa: Sic!, 2006.

Białecki, Tadeusz. Prasa Pomorza Szczecińskiego w latach 1945-1975. Szczecin: Wydawnictwo Naukowe Wyższej Szkoły Pedagogicznej w Szczecinie, 1978.

Bourdieu, Pierre. O telewizji. Panowanie dziennikarstwa, red. naukowa i przedmowa Małgorzata Jacyno. Tłum. Karolina Sztandar-Karolewska, Anna Ziółkowska. Warszawa: Wydawnictwo Naukowe PWN, 2009. 
Czejarek, Roman. Kolorowy Szczecin na starych pocztówkach. Łódź-Szczecin: Księży Młyn Dom Wydawniczy, 2013.

Giddens, Anthony. Nowoczesność i tożsamość. „Ja” i społeczeństwo w epoce późnej nowoczesności. Tłum. Alina Szulżycka. Warszawa: Wydawnictwo Naukowe PWN, 2010 .

Goban-Klas, Tadeusz. Cywilizacja medialna. Geneza, ewolucja, eksplozja. Warszawa: WSiP, 2005.

Jurszo, Robert. „IPN: Październikowa odwilż dała prasie na krótko większą swobodę”. Dostęp 5.04.2019. dzieje.pl.

Kania, Jan. „Podstawy metodologiczne wyodrębnienia mediów lokalnych”. Edukacja Humanistyczna 22 (2010), 1: 8-14.

Kania, Jan., Cieślak, Robert, red. Media lokalne w Szczecinie. Szczecin: Wydawnictwo Naukowe Uniwersytetu Szczecińskiego, 2011.

Karwowska-Lamparska, Alina. „Instytut Łączności kolebką polskiej telewizji”. Telekomunikacja i Techniki Informacyjne 3-4 (2009): 44-57.

Kuźma, Erazm. „O literaturze na Pomorzu”. W: Literatura na Pomorzu Zachodnim do końca XX wieku. Przewodnik encyklopedyczny, red. Erazm Kuźma, Inga Iwasiów, 11-50. Szczecin: Wydawnictwo „Kurier-Press”, 2003.

Matlak, Andrzej. „Nowa polska ustawa o radiofonii i telewizji”. Zeszyty Prasoznawcze 133 (1993), 1-2: 5-11.

Michalczyk, Stanisław Media lokalne w systemie komunikowania. Katowice: Wydawnictwo Uniwersytetu Śląskiego, 2000.

Mickelson, Sig. The Decade that Shaped Television News. CBS in the 1950s. Westport: Praeger Publishers, 1998.

Paziewski, Michał. Grudzień 1970 w Szczecinie. Szczecin: IPN, 2013.

Pleskot, Patryk. „Telewizja w życiu Polaków lat sześćdziesiątych”. Dzieje Najnowsze 34 (2002), 4: 115-135.

Puchalski, Zbigniew (2000). „Telewizja”. W: Encyklopedia Szczecina. Tom 2. P-Ż, red. Tadeusz Białecki, 518. Szczecin: Uniwersytet Szczeciński, 2000.

Rancière, Jacques. Dzielenie postrzegalnego. Estetyka i polityka. Tłum. Maciej Kropiwnicki i Jan Sowa, wstęp Magda Pustoła. Kraków: Koroporacja Ha!art, 2007.

Shuster, Martin. New Television. The Aesthetics and Politics of a Genre. Chicago: University of Chicago Press, 2017.

Urry, John. Socjologia mobilności. Tłum. Janusz Stawiński. Warszawa: Wydawnictwo Naukowe PWN, 2009. 


\begin{abstract}
AbstrakT
Celem artykułu jest wskazanie związków estetyki i polityki na przykładzie funkcjonowania szczecińskiej telewizji w latach sześćdziesiątych. Szczecin, od początku istnienia regionalnego ośrodka TVP, kojarzy się przede wszystkim z przemysłem morskim i stoczniowym, portem, zawodem marynarza, sportami wodnymi, spędzaniem wolnego czasu nad rzeką, jeziorem czy brzegiem morza. Te cechy charakterystyczne Szczecina niejednokrotnie podkreślano estetycznym wymiarem filmów i materiałów telewizyjnych z tamtego okresu - na przykład ich nieodłącznym elementem jest dźwięk okrętowej syreny - które miały wyraźnie perswazyjny, propagandowy charakter. Szczecińską telewizję tworzyli przy tym artyści - radiowcy, aktorzy, pisarze - których praca stanowiła styk dwóch przestrzeni: estetycznej i politycznej.
\end{abstract}

\title{
Szczecin Television Centre in the 1960s: Aesthetic and politics
}

\begin{abstract}
The purpose of this article is to demonstrate the connections between aesthetic and politics as exemplified by the Szczecin Television Centre in the 1960s. Szczecin, since the establishment of the regional centre of the Polish Television (TVP), has been associated primarily with the marine and shipbuilding industry, the port, the profession of seaman, water sports, spending free time at the riverside, by the lake or at the seashore. These characteristic features of Szczecin were repeatedly emphasized by the aesthetic dimension of the films and television materials of that time period - e.g. their inherent element was the sound of a ship's siren - which had clearly persuasive, propaganda character. The Szczecin television was created by the artists - radiomen, actors, authors, whose work was situated at the junction of two spaces: aesthetic and politic.
\end{abstract}

